\title{
A Brief Overview of Government, Law and Order, and Social Matters in the Tari District
}

\author{
Noel H. Walters
}

The 2002 national election highlighted the extent of anarchy throughout the Tari District and greater Huli area - Koroba, Komo and Magarima. Similar situations exist in other regions of the Southern Highlands Province. Early indications of the now rampant situation were observable 15 years ago. What started as pockets of anarchy have now developed to cover the entire province.

\section{Key factors}

Some of the many factors contributing to the present situation in Tari will be briefly discussed; most also apply to other provincial locations.

\section{Social evolution}

Social evolution has always been apparent in Huli society, but this process increased in intensity 15 years ago and in rapidity during the last five years.

The younger generation, up to 35 years of age, has little or no regard for the norms and values in which their fathers and grandfathers were indoctrinated. These were tenets which regulated action and social behaviour within the clan and behaviour towards other clans. The traditional 'bigman' system operated in this social system. It has almost disappeared.

Often the clans and subclans no longer have unity of purpose. Positive behaviour among peers and towards elders is not practised by many of the younger generation. The authority of elders is constantly challenged and physical injury and sometimes death are the result.

\section{Illegal gun culture}

In recent years there has been a proliferation of illegal weapons throughout the highlands. Possession of weapons is now regarded as a right by an ever-increasing number of the younger Huli generation. It has become one of the means by which some aspects of the present social situation are regulated. Misery, deprivation, confusion, death, injury, stealing, destruction of property and road blocks are some of the results of the illegal gun culture.

People often live in fear at their residential locations and have to move out during uncontrollable clashes; this equates to being refugees in their rightful areas. The right to pass safely along public roads is often endangered by gun-toting thugs. 
Such illegal acts are assisted by poor road conditions. Gang rapes of women are frequent occurrences.

\section{Compensation}

Traditional compensation generally aimed to right wrongs within the group and restore equanimity between groups. Strict rules and regulations were observed in the implementation of compensation arrangements.

The traditional compensation process cannot be satisfactorily applied to the present social situation. The use of automatic weapons often results in many deaths and much destruction of property in a short time span. There is not enough wealth, which comes mainly from the pig culture and cash, to compensate for what is occurring in the ever-changing social process. Excessive compensation demands are now used as a weapon to further suppress opponents.

\section{Lack of government}

At the time of writing (mid-2003) there was no effective government at Tari, at any level. This has been the situation for quite some time. Tari is a gazetted town. In fact it is a run down non-functioning district station with a few remaining relics of what used to operate in a bygone era. Such a situation occurs in many parts of the country. Some examples of the vandalisation of Tari, with no state action, are as follows:

- Encroachment on state land: people have made gardens on station land and graze their pigs at various locations.

- Police house previously occupied by OIC: windows taken, walls removed and some furniture stolen.

- Police house near police barracks: walls removed, hot water system taken.

- Single quarters, Tari Hospital: generally vandalised and parts of the building carted away.

- Bank building: doors broken, furniture (tables, chairs, washing machine, etc.) stolen.

- Main office building: flyscreens broken, louvers stolen.

- Airstrip: some fence wire and gates stolen, enabling people to walk across airstrip, thus causing a safety hazard.

- Education Centre (located about 200 metres from the police station): this is supposed to be the 'engine room' for Tari district education matters. There have been cuts in the perimeter fence, slashing of flyscreens, removal of louvers and frames, ransacking of filing cabinets, removal of electrical fittings and removal of the kitchen sink. Two buildings in the Centre were burnt after the recent election chaos.

- Tari rugby league field (located across a road from the police barracks): iron posts and wire fencing and a small grandstand were provided as a PJV tax 
credit scheme project. The wire and posts were stolen and the grandstand dismantled and carted away.

The following is a list of serious crimes committed in the precincts of Tari station in recent years. No one has been brought to account for any of these incidents; no coordinated government control exists.

- Police station burnt down.

- An Air Niugini office security murdered; no successful prosecution.

- Bromley and Manton manager shot dead; no one successfully prosecuted.

- A PJV employee murdered.

- Purani man murdered.

- Bank robberies (two).

- Menduli store robbed twice.

- Fuel service station robbed.

- Public service payroll from Mendi stolen at airstrip.

- Hospital female staff attacked and raped.

- House burglaries.

These two lists cover illegal acts around Tari station. The mind boggles at the extent of serious crime which occurs continually in the Tari District's rural environs.

\section{Police}

Police is a national government function. Some police stationed at Tari have become compromised by the community, through alcohol, women and various dubious activities. This has been going on for some time. There is little or no ability to deal with crime emanating from rapid social change.

In October 2000 I had a brief but interesting meeting with the mobile squad's commander in Tari. During discussions he said that no functioning government system existed in Tari; that the police, alone, could not rectify the negative law and order situation; that there was no functioning local-level government system at Tari which could contribute to bettering the law and order situation. The commander was disappointed that no government officers attended a community meeting, at Paijaka, on law and order matters.

\section{Courts}

Courts are a national government function. Major court work has not functioned in Tari for several years. When people are arrested they are held in the police cell for days before being taken to Mendi and charged before a court. 


\section{Health}

Health is a provincial government function. Tari Hospital is the major hospital for the greater Huli area. It is a district hospital under the relevant act. It used to have a compliment of four doctors a long time ago. The most recent appointment was stationed at Tari for several months in 2000, before he went to Mount Hagen in early 2001. I suspect that because of the run-down condition of the Tari Hospital it was deemed that the doctor's services could be better used in Mount Hagen.

Most aid posts are also in a run-down condition, and reasonable health services do not exist. No positive action has come from provincial headquarters, Mendi, to help rectify the unsatisfactory situation.

\section{Education}

Education is a provincial government function. Generally, the education system throughout Tari District is in a run-down state, and has been for a long time. In a ten-day working fortnight many schools operate only five days. Teachers use the other five days to try and access their pay from Mendi.

There is no local-level government system to help service teachers at their workplace. No effort has been made at provincial level to rectify the situation.

\section{Provincial government personnel}

Mendi divisional sectoral heads do not visit Tari or report on problems faced by their district counterparts in health, education and other matters. No remedial action is forthcoming from Mendi. The provincial level of government has no relevance to the majority of people in the greater Huli area. Over recent years there has been closure of government departments once represented at Tari. These include Works, Plant and Transport, CIS and the Welfare Office.

\section{Local-level government and district administration}

There are four local-level government councils within the Tari District. None of these operates as required by the relevant act. Local-level government is the one closest to the people and should be a focal point for rural people's attention. Unfortunately this is not the case.

District administration should provide the framework within which the district activities of all levels of government are coordinated. It does not.

Rural extension work is not done: neither rural health extension, agricultural extension, nor general face-to-face contact between government and the people. There is no continuous reporting on social developments or law and order matters in the district. 
Well trained, motivated and disciplined officers, at all levels of government in the district, should act in a coordinated way to explain important government policies to the people, and to ensure that policies are implemented and reporting requirements met. Unfortunately the Tari District lacks any meaningful overall government presence.

\section{Members of parliament}

If there has ever been any representation of people within the Tari-Pori electorate it has been only for that group from which the member came. The larger population has been ignored. In many instances sections of the larger group are regarded as the enemy.

During the five years (1997-2002) of overall government neglect of the district electorate, the member did not seem to worry about matters of serious concern: the station was vandalised; people were not able to post letters or access banking facilities; law and order problems escalated; road conditions further deteriorated; medical and education services declined; and so on.

If the member was not concerned for the wellbeing and safety of the majority of people, and the provision of basic services to which they have a right, one can only wonder what motivated him to become a member. Obviously the concept of 'government of the people, by the people, for the people' is a foreign one.

\section{Post-election activities}

Developments since the 2002-2003 elections have included: the destruction of more bridges; looting of the Bromley and Manton store; vandalisation and looting of the Menduli store; burning of buildings at the education Centre; closure of the MAF office; closure of Sullivans; cancellation of Air Niugini flights; roaming armed gangs, increasingly frequent road blocks and hold-ups. Bashings and rape have also occurred.

Bromley and Manton brought supplies in from Mount Hagen by convoy. All shop plant and equipment, fittings and the like were loaded and taken back to Mount Hagen. Since then there have been reports that the vacant staff houses have been broken into and items stolen.

The Dauli Teachers College has been closed and students and staff evacuated to Mount Hagen. From there they will go to their home destinations. Prior to closure, it was reported that a lecturer's house was broken into and that a female coastal student was raped.

Group disputes before and during the election period will have some form of resolution, peaceful or otherwise, as time passes. The number of dead and wounded and the extent of destruction of property arising out of group warfare have not been reported for many years. An efficient administration would keep track of such things. 


\section{What to do}

Huli society is changing and there is no operating government to help people get through what is often a chaotic, lawless and painful process. This has been the situation for a long time.

Recently there has been recurring damage to the Hides-Porgera electricity transmission line in rural Tari locations. Notes which have been left at locations where pylons have been felled express anger towards the various levels of government, references to political concerns, and demands for services and infrastructure to be restored throughout the Tari District.

Gold cannot be produced when power is cut to the Hides power station. Because of the worsening situation the PJV has been considering withdrawing. If this were to happen, the signal would be quickly picked up by would-be investors in the PNG-Queensland Gas Pipeline venture.

There has to be political will at the highest level of government in Port Moresby to rectify the existing unsatisfactory situation. This requires a step-by-step plan, with adequate resources - financial, technical, and human - to re-establish a sound base of law and order. At the same time, a coordinated and integrated framework must be developed for all levels of government in Tari District. This is prerequisite for delivery of services and for social and economic development.

What has to happen will take several years. However, an immediate start, with full political support, is necessary. The people have to see that something is happening. When this is achieved, measures will have to be taken to ensure sustainability of the restored government system.

\section{Conclusion}

Some people are of the opinion that what is happening in the Huli area, and other parts of the highlands, is what the people deserve - it is the 'highlands way'. Such an attitude is small-minded and irresponsible.

Most Southern Highlanders want a stable law and order situation that allows them to go about the daily requirements of life unimpeded and without fear. There should be health services for children and adults. Postal and banking services should be available. Education services at all levels should be operating at a national standard. Small and large business should be able to develop and run in a safe environment. Businesses should not be closed by pillage and plunder, roadblocks, and other illegal acts. Firm practical action should commence as soon as possible, and be supported by the necessary resources. 